\title{
From the desk of Editor-in-Chief
}

doi: https://doi.org/10.3329/jemc.v9i3.43241

\begin{abstract}
Alhamdulillah! With the publication of this issue we are completing nine years of publication of Journal of Enam Medical College. This is a great success and landmark in the trajectory of the journal. We share this success with the contributors, reviewers and faculties and authority of the college without whose active and sincere cooperation it would not have been possible to publish the journal regularly and timely. We are very grateful to all of them.
\end{abstract}

The flow of paper submission for publication in the Journal of Enam Medical College continues to be very good. Papers are flowing in also from outside the country. This has been because of the quality of the journal and regular and timely publication.

Participation in the national and international conferences promotes exchange of ideas among the academics. During the last four months period from May 2019 to August 2019 many faculties of our institution participated in different conferences and training programmes outside the country. They have earned reputation for our institution. We congratulate all of them.

With all the best wishes.

\author{
Prof. Md. Aminul Haque Khan \\ Editor-in-Chief
}

